\begin{tabular}{l}
\hline Nuansa Journal of Arts and Design \\
Volume 5 Nomor 1 April 2021 \\
e-ISSN: 2597-405X dan p-ISSN: 2597-4041 \\
\begin{tabular}{|l|l|}
\hline (c) This work is licensed under a Creative Commons Attribution \\
\hline
\end{tabular} 4.0 International License
\end{tabular}

\title{
Eksplorasi Modul Pembelajaran dengan Materi Membuat Poster Menggunakan Limbah Pohon Pisang
}

\section{Syafitra Rais \\ Penulis}

Keywords :
Pengembangan modul;
Poster;
Limbah pohon pisang;

Corespondensi Author

PPs Universitas Negeri Makassar

Email: syafitra22feb@gmail.com

\begin{abstract}
ABSTRAK
Penelitian ini bertujuan untuk mengembangkan modul pembelajaran poster dengan menggunakan limbah pohon pisang yang valid dengan berlokasi di SMAN 1 Simboro Provinsi Sulawesi Barat. Model penelitian dan pengembangan yang digunakan adalah Model 4-D yang terdiri atas empat tahap, dan disederhanakan menjadi tiga tahap yaitu, tahap perencanaan (Define), tahap perancangan (Design), dan tahap pengembangan (Develop) hanya pada tahap revisi beserta penilaian validator. Penyususan dan pengembangan modul pembelajaran ini divalidasi oleh satu ahli media dan satu ahli materi. Instrumen pengumpulan data yang digunakan berupa angket untuk validator ahli media dan angket untuk ahli materi. Teknik analisis data yang digunakan yaitu deskriptif kualitatif. Data hasil penilaian modul pembelajaran terlebih dahulu dihitung secara kuantitatif kemudian diekuivalenkan menjadi data kualitatif. Hasil Penelitian menujukkan bahwa secara umum pengembangan modul pembelajaran poster dengan menggunakan limbah pohon pisang yang telah divalidasi memenuhi kriteria kevalidan sehingga layak dilanjutkan uji coba untuk mengukur kepraktisan dan keefektifan materi pembelajaran.
\end{abstract}

\section{PENDAHULUAN}

Tujuan pendidikan nasional adalah tujuan yang ingin dicapai secara nasional, yang dilandasi oleh falsafah suatu negara. Sifat tujuan ini ideal, komprehensip, utuh dan menjadi induk bagi tujuan-tujuan yang ada dibawahnya. Selain itu berdasarkan Undang-Undang No.20 tentang sistem pendidikan nasional pada pasal 3 menyatakan Pendidikan nasional berfungsi mengembangkan kemampuan dan membentuk watak serta peradaban bangsa yang bermanfaat dalam rangka mencerdaskan kehidupan bangsa (Lazwardi, 2017:110).

Upaya mencerdaskan bangsa ini dapat terjadi jika ada dukungan dari berbagai pihak yang berpartisipasi dalam proses pencapaian keberhasilan tersebut. Pihak ini tidak lain adalah pemerintah, guru hingga orang tua dan peserta didik itu sendiri. Guru dalam fungsinya dapat disebut sebagai "arsitek pembelajaran", merancang pembelajaran secara baik dan sempurna. Peran guru dapat dijalankan dengan sempurna apabila dilandasi dengan rancangan pembelajaran yang baik, dalam proses pembelajaran dapat diukur ketercapaian tujuan yang telah ditetapkan. Secara spesifik guru memiliki peran utama yaitu mendidik, mengajar dan melatih atau membimbing (Juhji, 2016:53).

Selain itu, diperlukan media pendukung dalam proses pembelajaran yang berfungsi untuk mempermudah tercapainya tujuan pembelajaran 
dalam proses pembelajaran. Dengan menggunakan media pembelajaran yang menarik peserta didik dapat lebih tertarik lagi untuk belajar dan meningkatkan pemahaman terhadap suatu materi. Jenis media pembelajaran yang dapat digunakan seperti buku, modul, lembar kerja peserta didik (LKPD), hand out dan lain sebagainya.

Media adalah segala alat fisik yang dapat menyajikan pesan serta merangsang siswa untuk belajar. Buku, film, kaset, film bingkai adalah contoh-contohnya. Salah satu media ajar yang dapat digunakan siswa untuk belajar mandiri adalah dalam bentuk modul. Modul merupakan bahan ajar yang dapat digunakan oleh siswa untuk belajar secara mandiri dengan bantuan seminimal mungkin dari orang lain. Pendapat-pendapat tersebut menjelaskan bahwa dalam proses pembelajaran dibutuhkan media untuk menarik perhatian dan rasa ingin tahu siswa terhadap pelajaran, salah satu media yang dapat dikembangkan adalah berupa modul karena dapat digunakan siswa untuk belajar mandiri. Pengembangan modul ini mendukung penerapan kurikulum 2013, dimana guru dituntut untuk membimbing siswa untuk lebih aktif dalam pembelajaran (Rosa, 2015:54)

Hakikatnya pengembangan adalah upaya pendidikan baik formal maupun non formal yang dilaksanakan secara sadar, berencana, terarah, teratur dan bertanggung jawab dalam rangka memperkenalkan, menumbuhkan, membimbing, mengembangkan suatu dasar kepribadian yang seimbang, utuh, selaras, pengetahuan, keterampilan sesuai dengan bakat, keinginan serta kemampuan-kemampuan, sebagai bekal atas prakarsa sendiri untuk menambah, meningkatkan, mengembangkan diri ke arah tercapainya martabat, mutu dan kemampuan manusiawi yang optimal dan pribadi mandiri (Wiryokusumo, 2011:81).

Pelajaran seni budaya dan keterampilan diberikan di sekolah karena keunikan, kebermaknaan dan kebermanfaatan kebutuhan perkembangan peserta didik, yang terletak pada pemberian pengalaman estetik dalam bentuk kegiatan berekspresi dan berapresiasi melalui pendekatan, belajar dengan seni, belajar melalui seni dan belajar tentang seni peran ini tidak dapat di pelajaran lain.

Dalam penelitian ini media ajar yang digunakan adalah modul Menurut (Aditia dan Muspiroh, 2013:8) modul adalah sarana pembelajaran dalam bentuk tertulis atau cetak yang disusun secara sistematis, memuat materi pembelajaran, metode, tujuan pembelajaran berdasarkan kompetensi dasar atau indikator pencapaian kompetensi, petunjuk kegiatan belajar mandiri (self instructional), dan memberikan kesempatan kepada siswa untuk menguji diri sendiri melalui latihan yang disajikan dalam modul tersebut.

Berdasarkan observasi yang telah peneliti lakukan, siswa kelas X SMA Negeri 1 Simboro belum mendapat pengetahuan dasar tentang poster, karena referensi yang digunakan hanya berupa buku teks dan tidak ada media pendukung lain yang digunakan oleh guru mata pelajaran. Buku pelajaran seni budaya yang digunakan hanya memberikan materi secara umum namun tidak memberikan penjelasan secara spesifik tentang proses pembuatan karya seni rupa. Faktor lain yang menjadi hambatan yaitu sulit ditemukannya bahan dan peralatan dalam proses pembuatan karya seni rupa seperti cat minyak, cat air, cat poster dan lain-lain, hal ini dikarenakan lokasi sekolah jauh dari kota.

Berdasarkan penjelasan tersebut disimpulkan bahwa salah satu cara yang dapat dilakukan peneliti untuk membantu kelancaran. terlaksananya proses pembelajaran yaitu dengan membuat modul pembelajaran poster dengan menggunakan limbah pohon pisang. Dengan adanya modul ini diharapakan agar materi dapat tersampaikan dengan lebih rinci dan sistematis serta memudahkan peserta didik dalam berkarya seni.

Pemilihan pembuatan poster dengan menggunakan limbah pohon pisang, Limbah pohon pisang dipilih sebagai media berkarya bagi siswa dalam pembelajaran membuat poster dengan pertimbangan sebagai berikut:

1. Limbah pohon pisang mudah ditemukan di lingkungan sekitar sekolah.

2. Limbah pohon pisang yang mudah ditemukan mengurangi biaya peserta didik dalam pengadaan bahan dalam berkarya seni rupa.

3. Pelepah pisang merupakan media baru bagi siswa SMA Negeri 1 Simboro Sulawesi Barat sehingga dapat menambah pengalaman dalam berkarya seni rupa dan menambah rasa peduli dalam memanfaatkan potensi alam lokal yang ada.

\section{METODE}

Jenis penelitian ini yaitu Research and Development (R\&D). Menurut (Sugiyono, 
2010:34) penelitian dan pengembangan adalah metode penelitian yang digunakan untuk menghasilkan produk tertentu dan menguji keefektifan produk tersebut. (Sugiyono, 2010:3334) menjelaskan bahwa jenis penelitian ini bertujuan untuk menghasilkan atau menciptakan suatu produk yang baru atau dapat juga sebagai penyempurna suatu produk yang sudah ada sebelumnya. Maka dapat ditarik kesimpulan bahwa penelitian pengembangan adalah suatu usaha ilmiah yang dilakuakan untuk menyempurnakan suatu produk serta menguji keefektifan produk tersebut. Mengacu pada model penelitian 4-D yang terdiri dari 4 tahap yaitu, pendefinisian (Define), perancangan (Design), pengembangan (Development) dan penyebaran (Dissemination). Bagan model pengembangan model 4-D Thiagarajan dkk (1974).

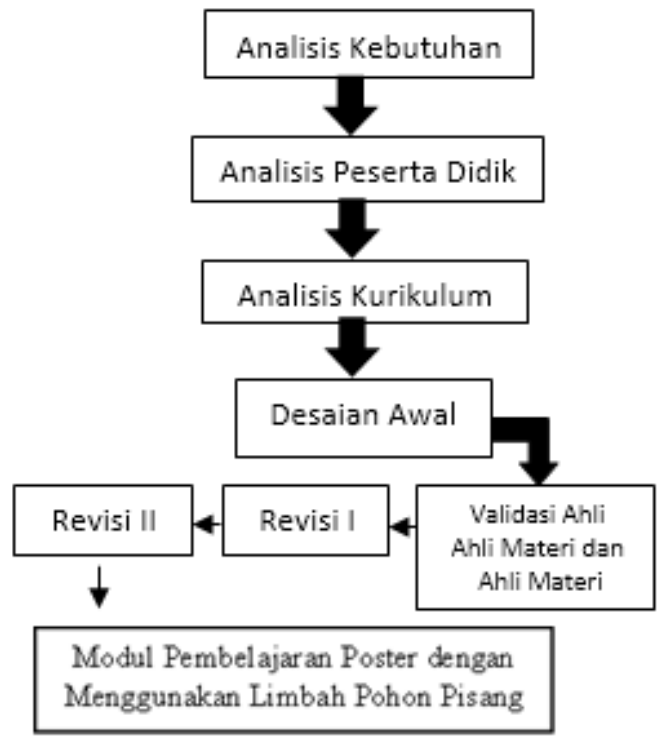

Gambar 1. Skema pengembangan 4D

Terdapat 4 tahap dalam pengembangan model 4-D yaitu, pendefinisian (Define), perancangan (Design), pengembangan (Development) dan penyebaran (Dissemination). 4 tahap tersebut dijabarkan sebagai berikut:

\section{Tahap Pendefinisian (Define)}

Pada tahap ini dilakukan analisis kebutuhan terhadap siswa kelas X SMA Negeri 1 Simboro.

\section{a. Analisis Kebutuhan Belajar}

Untuk mengetahui masalah yang dihadapi oleh siswa kelas $\mathrm{X}$ dalam pembelajaran seni budaya maka dilakukan analisis kebutuhan mengajar. Data diperoleh dengan cara observasi pada saat kegiatan pembelajaran. Sehingga ditetapkan bahwa diperlukannya modul pembelajaran untuk mempermudah proses pembelajaran di kelas X SMA Negeri 1 Simboro khusunya materi poster.

\section{b. Analisis Karakter Peserta Didik}

Untuk mengetahui karakter dari masingmasing peserta didik pada kelas $\mathrm{X}$ dilakukan analisa tingkat pengetahuan dalam belajar serta dilakukan analisa tingkat ekonomi dan latar belakang peserta didik. Menurut Muhaemin (2018:34) karakteristik peserta didik pada perlu diketahui untuk melihat keterampilan, aspek psikologi peserta didik serta tingkat pengetahuannya.

\section{c. Analisis Kurikulum}

Dilakukan dengan cara menganalisa kesesuaian antara kurikulum yang digunakan dengan kompetensi inti (KI) dan kompeteni dasar (KD).

1) Perancangan (Design)

Pada tahap ini peneliti merancang suatu bahan ajar berupa modul pembelajaran berupa modul pegangan guru dan modul pegangan siswa yang sesuai dengan kurikulum yang digunakan di dalam sekolah. Rancangan instrumen validasi (materi dan kegrafikaan) juga dilakukan pada tahap ini untuk mengukur kualitas produk yang dihasilkan.

2) Pengembangan (Development)

Tujuan dari tahap pengembangan adalah untuk menghasilkan draf final perangkat pembelajaran yang baik. Kegiatan pada tahap ini adalah :

a) Validasi ahli

Hasil dari rancangan awal yaitu draft I divalidasi oleh validator, dan revisi digunakan sebagai dasar perbaikan perangkat pembelajaran untuk mendapatkan draft II.

b) Uji Keterbacaan

Uji keterbacaan dilakukan kepada beberapa peserta didik dan validator untuk melihat apakah perangkat pembelajaran berupa LKM, instrumen tes hasil belajar, dan RPP dapat terbaca dengan jelas dan mudah dipahami.

3) Penyebaran (Dissemination)

Tujuan dari tahap ini adalah untuk melakukan tes validasi terhadap perangkat 
pembelajaran yang telah diuji cobakan dan direvisi, kemudian disebarkan ke lapangan.

\section{HASIL DAN PEMBAHASAN}

\section{Hasil}

Hasil pengumpulan data dari kegiatan observasi di SMAN 1 Simboro menunjukan bahwa kegiatan pembelajaran siswa kelas $\mathrm{X}$ berpedoman pada kurikulum 2013. berikut:

Data hasil observasi dijelaskan sebagai

\section{Tahap Pendefinisian (Define)}

a. Analisis kebutuhan belajar

1. Analisis kebutuhan belajar dilakukan pada saat kegiatan pembelajaran. Dengan hasil analisis sebagai berikut:

2. Dalam proses belajar-mengajar sumber pembelajaran yang digunakan masih sangat minim. Sehingga kegiatan pembelajaran hanya terpusat pada guru.

3. Sumber belajar hanya membahas tentang pengetahuan kognitif atau KD 3, namun pada pengetahuan psikomotorik atau KD 4 tidak ditemukan sumber belajar. Sehingga kegiatan belajar lebih terfokus pada teori namun kurang pada kegiatan praktik

4. Kegiatan pembelajaran hanya menggunakan satu buku dimana buku tersebut merupakan buku yang digunakan guru sekaligus juga digunakan peserta didik.

\section{b. Analisis karakter peserta didik}

Tahap ini bertujuan untuk mengetahui karakter peserta didik dengan melakukan analisis kemampuan dan analisis latar belakang peserta didik. Hasil observasi yang diperoleh adalah sebagai berikut:

1. Peserta didik kelas $\mathrm{X}$ di SMAN 1 Simboro, berusia 16-18 tahun.

2. Tingkat ekonomi peserta didik menengah kebawah, sehingga cukup sulit jika dalam pembelajaran seni rupa khususnya kegiatan praktikum menggunakan media yang memiliki harga relatif tinggi.

3. Sulitnya mendapatkan alat dan bahan dalam kegiatan praktikum seni rupa karena lokasi sekolah yang jauh dari kota.

c. Analisis Kurikulum

Analisis kurikulum untuk mengetahui kurikulum yang digunakan di SMAN 1 Simboro, setelah melakukan observasi maka di dapat beberapa data sebagai berikut:

1. Kurikulum yang digunakan yakni Kurikulum 2013 untuk semua jenjang tingkatan. Menurut Kepala Sekolah kurikulum ini belum lama diterapkan namun demi menyesuiakan dengan kurikulum pendidikan yang terbaru kami berusaha untuk menyesuikan diri secara perlahan.

2. Kompetensi dasar pada kelas $\mathrm{X}$ disesuaikan dengan silabus yang digunakan.

3. Buku yang digunakan adalah terbitan Kementrian Pendidikan dan Kebudayaan yang diterbitkan tahun 2017. Dengan acuan kurikulum 2013.

4. Materi maupun praktek yang diajarkan disesuaikan dengan mempertimbangkan tingkat kemudahan dalam memperoleh bahan dan tingkat kemampuan peserta didik.

\section{Tahap Perancangan (Design)}

a. Perancangan Awal Modul Pembelajaran

Pengembangan modul pembelajaran poster dengan menggunakan limbah pohon pisang diawali dengan membuat rancangan desain bahan ajar berupa modul pembelajaran yang disesuaikan dengan kurikulum yang berlaku di SMAN 1 Simboro yang menggunakan kurikulum 2013 dalam pembelajarannya, sehingga Kepala Sekolah menyarankan untuk mengembangkan modul sesuai dengan kurikulum 2013. Modul yang dikembangkan yaitu modul pegangan guru dan modul pegangan siswa. Modul pegangan siswa berisi petunjuk atau cara penggunaan modul, uraian materi, peta konsep, rangkuman isi materi, soal-soal latihan, kunci jawaban soal latihan, glosarium, daftar pustaka, serta profil penulis. Sedangkan pada modul guru dilengkapi RPP, kunci jawaban dan rubrik penilaian.

Isi modul menggunakan kertas HVS dengan ukuran A4, 70 gr. Jenis tulisan (Font) utama yaitu Berlin Sans FB Demi dan tambahan yaitu Times New Roman ukuran font 12, spasi 1.5. Modul ini dilengkapi dengan gambar sebagai penjelas dan karya seni grafis sehingga membuat tampilan modul menjadi lebih menarik. 


\section{b. Merancang Instrumen}

Langkah berikutnya yaitu perancangan instrumen penilaian modul pembelajaran berupa angket yang terdiri dari angket untuk ahli materi dan angket untuk ahli media. Contoh lembar evaluasi penilaian ahli media dan ahli materi dapat dilihat pada lampiran halaman berikutnya.

\section{c. Melakukan Validasi}

Validasi dilakukan oleh dua ahli yaitu Dr. Moh. Thamrin Mappalahere, M.Pd. ditunjuk sebagai validator ahli materi dan Dr. Aswar, M.Ds. ditunjuk sebagai validator ahli media. Validasi dilakukan untuk menguji kelayakan terhadap modul yang telah dirancang oleh peneliti.

\section{Pembahasan}

Hasil penelitian yang diperoleh berupa modul pembelajaran poster dengan menggunakan limbah pohon pisang yang digunakan oleh siswa kelas $\mathrm{X}$ pada jenjang SMA/MA dengan menggunakan model pengembangan 4-D dimana tahapannya yaitu pendefinisian (define), perancangan (design), pengembangan (development) dan penyebaran (dissemination).

\section{a. Hasil validasi oleh ahli media}

Untuk memperoleh data dari ahli media, maka dibuatlah angket dengan empat indikator untuk menilai bentuk fisik modul yang dikembangkan.

Penilaian oleh Ahli Media terdiri dari 4 aspek yaitu, desain sampul modul (cover), desain isi modul, efek media terhadap strategi pembelajaran, dan penilaian kelayakan tampilan menyeluruh.

Penilaian desain sampul modul (cover) terdapat 4 item penilaian yang menunjukkan nilai sangat baik dan 2 item menunjukan nilai baik, dengan jumlah skor 28 dan nilai ratarata adalah 4,6, jika diubah dalam bentuk nilai kualitatif, maka nilai tersebut dapat dikatakan "sangat baik".

Penilaian desain isi modul terdapat 8 item penilaian yang keseluruhan memperoleh nilai "sangat baik" dengan jumlah skor 40 dan nilai rata-rata adalah 5 , jika diubah dalam bentuk nilai kualitatif, maka nilai tersebut dapat dikatakan "sangat baik".

Penilaian efek media terhadap strategi pembelajaran terdapat 4 item dengan keseluruhan mendapatkan nilai sangat baik dengan jumlah skor 20 dan nilai rata-rata adalah 5, jika diubah dalam bentuk nilai kualitatif, maka nilai tersebut dapat dikatakan "sangat baik".

Penilaian kelayakan tampilan menyeluruh terdapat 7 item dengan 1 item mendapatkan nilai baik dan 6 item mendapatkan nilai sangat baik. Sehingga jumlah skor 34 dan nilai rata-rata adalah 4,8, jika diubah dalam bentuk nilai kualitatif, maka nilai tersebut dapat dikatakan "sangat baik".

Penilaian menyeluruh oleh ahli media mendapatkan nilai sangat baik dari empat item penilaian, jumlah skor 19,4 dan nilai rata-rata adalah 4,8 , jika diubah dalam bentuk nilai kualitatif, maka nilai tersebut dapat dikatakan "sangat baik".

\section{b. Hasil validasi oleh ahli materi}

Data dari ahli materi diperoleh melalui angket dengan dua indikator penilaian yang terdiri dari, aspek pembelajaran dan aspek substansi materi.

Penilaian pembelajaran terdapat 11 item penilaian dengan 7 item menunjukan nilai sangat baik dan 4 item menunjukan nilai baik. Jumlah skor 51 dan nilai rata-rata adalah 4,6, jika diubah dalam bentuk nilai kualitatif, maka nilai tersebut dapat dikatakan "sangat baik".

Penilaian substansi materi terdiri dari 5 item dengan 2 item memdapat nilai sangat baik dan 3 item mendapat nilai cukup, dengan total skor 22 dan nilai rata-rata adalah 4,4, jika diubah dalam bentuk nilai kualitatif, maka nilai tersebut dapat dikatakan "baik".

Penilaian menyeluruh oleh ahli materi mendapatkan nilai sangat baik dan baik dari dua item penilaian, jumlah skor 9 dan nilai 
rata-rata adalah 4,5, jika diubah dalam bentuk nilai kualitatif, maka nilai tersebut dapat dikatakan "sangat baik".

Hasil skor akhir menunjukan bahwa modul yang sudah dikembangkan sudah layak untuk digunakan dan dapat mendukung kegiatan pembelajaran.

\section{SIMPULAN DAN SARAN}

Dari hasil penelitian dan pembahasan dapat disimpulan bahwa prosedur pengembangan modul pembelajaran dilakukan dengan 3 tahapan diantaranya: tahap pertama adalah pendefinisian (define), tahap kedua adalah perancangan (design), dan tahap ketiga adalah pengembangan (development). Setelah melalui tiga tahapan tersebut dapat ditarik kesimpulan bahwa modul pembelajaran poster dengan menggunakan limbah pohon pisang sudah layak untuk digunakan pada kelas $\mathrm{X}$ jenjang SMA/MA khususnya di SMAN 1 Simboro Provinsi Sulawesi Barat.

Selain kesimpulan dapat pula diberikan saran untuk penelitian ini. Saran terhadap hasil penelitian adalah sebagai berikut:

1. Saran dissemination (penyebaran) penyebaran modul ini dapat dilakukan apabila sekolah yang akan menggunakan modul ini memiliki permasalahan dalam pembelajaran seperti tingkat ekonomi peserta didik yang rendah, kesulitan menemukan bahan praktikum seni budaya dan kesesuaian materi yang akan disampaikan yaitu materi poster.

2. Perlunya dilakukan uji kepraktisan dan keefisienan terhadap modul pembelajaran ini sehingga modul pembelajaran ini memenuhi kriteria kelayakan dari segi kevalidan materi, kepraktisan dan keefektifan penggunaan modul.

\section{DAFTAR RUJUKAN}

Aditia, M.T., Muspiroh, N. 2013. Pengembangan Modul Pembelajaran Berbasis Sains, Lingkungan, Teknologi, Masyarakat dan Islam (Salingtemasis) dalam Meningkatkan Hasil Belajar Siswa pada Konsep Ekosistem Kelas X Di Sma NU (Nadhatul Ulama) Lemahabang Kabupaten Cirebon.
Scientiae Educatia: Jurnal Pendidikan Sains.

Juhji, J. 2016. Peran Urgen Guru dalam Pendidikan. Banten: Studia Didaktika.

Lazwardi, D. 2017. Manajemen Kurikulum sebagai Pengembangan Tujuan Pendidikan. Lampung: Al-Idarah, Jurnal Kependidikan Islam.

Muhaemin, M. 2019. Pengembangan Modul Teknik Pewarnaan Cat Air Pada Kegiatan Ekstrakurikuler Di Sekolah Menengah Pertama. Tesis: Univiersitas Negeri Makassar.

Rosa, F.O. 2015. Pengembangan Modul Pembelajaran IPA SMP Pada Materi Tekanan Berbasis Keterampilan Proses Sains. Jurnal Pendidikan Fisika.

Sugiyono. 2010. Metode Penelitian Kuantitatif, Kualitatif dan $R \& D$. Bandung: Alfabeta.

Thiagarajan, S. dkk. 1974. Instructional Development for Training Teachers of Expectional Children. Minneapolis, Minnesota: Leadership Training Institute. Special Education, University of Minnesota.

Wiryokusumo, Iskandar. 2011. Dasar-Dasar Pengembangan Kurikulum. Jogjakarta: Tangga Pustaka. 